This item was submitted to Loughborough's Research Repository by the author.

Items in Figshare are protected by copyright, with all rights reserved, unless otherwise indicated.

\title{
Evaluation of a natural workspace intervention with active design features on movement, interaction and health
}

PLEASE CITE THE PUBLISHED VERSION

https://doi.org/10.3233/WOR-205180

PUBLISHER

IOS Press

VERSION

AM (Accepted Manuscript)

PUBLISHER STATEMENT

The final publication is available at IOS Press through https://doi.org/10.3233/WOR-205180.

LICENCE

CC BY-NC-ND 4.0

\section{REPOSITORY RECORD}

Munir, Fehmidah, Joanna Yarker, Jennifer Duckworth, Yu-Ling Chen, Andrew Brinkley, Veronica Varela-Mato, Rachel Lewis, and Stacy Clemes. 2021. "Evaluation of a Natural Workspace Intervention with Active Design Features on Movement, Interaction and Health". Loughborough University.

https://hdl.handle.net/2134/14723775.v1. 
Evaluation of a natural workspace intervention with active design features on movement, interaction and health

Fehmidah Munir, ${ }^{1,2}$ Joanna Yarker, ${ }^{3}$ Jennifer Duckworth, ${ }^{1}$ Yu-Ling Chen, ${ }^{1}$ Andrew Brinkley, ${ }^{2}$ Veronica Varela-Mato, ${ }^{1,2}$ Rachel Lewis, ${ }^{3}$ Stacy Clemes ${ }^{1,2}$

${ }^{1}$ School of Sport, Exercise and Health Sciences, Loughborough University, UK, LE11 3TU

${ }^{2}$ National Centre for Sport and Exercise Medicine, School of Sport, Exercise and Health Sciences, University of Loughborough, UK, LE11 3TU

${ }^{3}$ Department of Organizational Psychology, Birkbeck, University of London, UK, W1CE 7HX

Email addresses:

Fehmidah Munir f.munir@lboro.ac.uk

Joanna Yarker j.yarker@bbk.ac.uk

Jennifer Duckworth jennifer@babelprojects.co.uk

Yu-Ling Chen y.chen2@lboro.ac.uk

Andrew Brinkley a.j.brinkley@lboro.ac.uk

Veronica Varela-Mato v.varela-mato@lboro.ac.uk

Rachel Lewis Rachel.lewis@bbk.ac.uk

Stacy Clemes s.a.clemes@lboro.ac.uk

Corresponding author: Fehmidah Munir, School of Sport, Exercise and Health Sciences, Loughborough University, Loughborough, Le11 3TU, UK. Email: f.munir@lboro.ac.uk 


\begin{abstract}
Background: There is increasing focus on designing workspaces that promote less sitting, more movement and interaction to improve physical and mental health.

Objective: This study evaluates a natural intervention of a new workplace with active design features and its relocation to a greener and open space.

Methods: An ecological model was used to understand how organisations implement change. Pre and post survey data from 221 matched cases of workers and accelerometery data $(n=50)$ were analysed.
\end{abstract}

Results: Results show a decrease in occupational sitting (-20.65 mins/workday, $p=.001)$ and an increase in workplace walking (+5.61 mins/workday, $p=.001)$ using survey data, and accelerometery data (occupational sitting time: -31.0 mins/workday, $p=.035$, standing time: +22.0 mins/workday, $p=.022$, stepping time: +11.0 mins/workday, $p=.001)$. Improvements in interaction, musculoskeletal pain and mental health were reported.

Conclusions: Application of the ecological model shows that the organisation understands how to target the built environment and social/cultural environment but not how to target behaviour change at the individual level.

Keywords: building design; workplace; physical activity; social interactions; ecological model 


\section{Introduction}

Active workplace designs encourage physical activity (e.g. sitting less, moving more) and greater social connectedness through adaptations to the built environment, workplace policies and culture [1]. These designs are impactful as they have the capacity to target and reach everyone in a workplace as opposed to specific workplace initiatives (e.g. step count challenges) and services (e.g. access to gyms) that frequently reach those who choose to opt-in $[2,3]$. Office workers are a sedentary population, spending $73 \%$ of time at work sitting $[4,5]$. In particular, over a third of their total sitting time at work is accrued in stretches of prolonged sitting (>30 minutes) [5]. This is problematic as high levels of occupational sitting are a modifiable risk factor for most non-communicable diseases and premature mortality [68], poor mental health $[9,10]$ and musculoskeletal problems such as neck and shoulder pain [11]; as well as harmful for work outcomes such as lower productivity [12], poor work engagement [13], and sickness presenteeism [14].

Active workplace design places greater emphasis on the organisation of workspace, unassigned and shared desks, space provision for supporting tasks and supporting technology that enables movement [15]. Combined with more prominent staircases, more open workspaces, sit-stand desks and stand-up meeting desks, these designs encourage and allow workers to sit less and move more frequently during the day to find the best place to focus on their work tasks [15]. It also allows for greater interaction and collaborative working [16]. There are reported benefits of active workplace designs on physical health [17] as well as on important work outcomes such as increased social interaction, satisfaction and task performance [18]. However, the effect on mental health is not clear [18] as other factors in the workplace environment such as poor or inconsistent heating, lighting, noise and air quality of the workplace environment can have a negative impact on health and wellbeing [19-22]. High levels of spatial density and unassigned desks at work can produce a sense of 
crowding, lack of privacy and personal control [23, 24], low levels of work satisfaction and task performance $[25,26]$.

The external neighbourhood environment of a workplace and how one travels to work all potentially influence physical activity behaviours in and around the workplace [27]. For example, nearby pleasant walkable environments may reduce physical movement inside the workplace as workers choose to walk during their breaks or hold walking meetings and then sit and work in the remaining time. Distance from home, density, connectivity, and land use diversity [28] will impact on how people travel to work, and both active (e.g. cycling) and passive commutes (e.g. driving) may affect how much workers move around work [29, 30]. Equally, high workload, tight work deadlines and the need for visibility by managers, or access to supportive technology may also affect how much workers are able to move around the building and accrue the health and social benefits of physical activity.

\subsection{An Ecological Perspective}

There is a significant gap in our understanding of how business organisations understand and implement active workplace design on their own. This can perhaps be best understood through the ecological framework [31, 32]. This theory-based framework suggests health behaviour, and more specifically here, physical activity, is influenced by four nested hierarchical levels: Individual determinants, social/cultural environment, built environment and the policy environment. At the individual level, characteristics such as, gender, age, racial/ethnic identity, knowledge and attitudes influence behaviour change. However, health behaviour is less impacted by individual knowledge and attitudes [33] and more influenced by the environments in which individuals live, play, learn or work in. The social/cultural environment includes the influence from social networks, social support systems from coworkers, managers and relevant others and the social norms and culture that operate within 
that environment. The built environment refers to not only to the building design, its stairways, workspace, office layout (open, closed), and workstations, but also to the nearby urban design, transport and green spaces. At the policy level, structural factors, rules and regulations also affect health behaviours. This includes workplace policies and processes, and job design and resources (financial, technological). All of these factors will influence not only the individual, their behaviours and their health, but also in how active workplace designs are implemented in the first place. Using the model in this context advances our knowledge and understanding of all the factors that impact health behaviours including the social determinants of health for active workplace designs. Most often, studies do not provide a complete perspective or how organisations attempt to implement behaviour change. We use this model to advance our understanding of how change is implemented by organisations who have no knowledge or training in using theory or effective behaviour change methods to achieve the change they desire in their workforce (see Figure 1).

In the current study, we evaluated the impact a natural intervention on the impact of a new workplace built using active workplace design features to improve the health and wellbeing of workers by encouraging less sitting, more movement and more interaction through flexible working and use of nearby open spaces and facilities. We use the socio-ecological framework to capture the 'active ingredients' of the workplace design and its surrounding environment. We hypothesised that compared to the 'old' building design and ways of working, the new building and its active workplace design will increase physical activity and social interaction among workers as well as higher satisfaction with the building design and outdoor spaces. We further hypothesised that the active workplace design will increase positive health and wellbeing outcomes. Finally, we hypothesised that the active workplace design will also improve organisational health outcomes such as sickness absence, engagement, job satisfaction and performance. 


\section{Method}

\subsection{Study Design}

This study had a pre-post design using mixed-method evaluation and took place between March 2018 and November 2018. Pre-move data were collected approximately two months prior to the relocation and post-data were collected two months post-move. Participants moved to the new location in four waves from June 2018 to September 2018. Ethical approval was obtained from Loughborough University's Human Participants Ethics Committee.

\subsubsection{Setting}

This study took place in a large UK regulatory agency employing 3924 workers in March 2018 who were located in two city-based buildings, within walking distance of each other in a built-up inner city business district. The area has a large indoor shopping mall, a marina nearby and two small public green spaces, but natural outdoor spaces and facilities are limited. The $34,000 \mathrm{~m}^{2} 15$ floor main building was fully occupied by the regulatory agency. Seventy workers occupied part of a floor in the second building. The buildings had open plan offices with limited break out areas, communal kitchens, lunch/coffee areas, centrally located printers and waste bins. The main building had a restaurant, gym (accessed externally), bicycle storage, lockers and shower rooms. Both buildings were built in the 1990s, were heavily reliant on the lifts for movement between floors and had minimal internal impact from its natural lighting. The buildings had physical Local Area Network (LAN) for internet capabilities and no WIFI. This meant workers were limited in moving around and using open workspaces. This also resulted in minimal hot desking behaviour despite a policy promoting hot desking, with staff usually working in the same area with the same people. 
The new building is located just outside the inner city in a district that has businesses and residential neighbourhoods with good infrastructure. The building is situated near indoor and outdoor sports and leisure facilities including an aquatics centre. Nearby, there are accessible large public green open spaces including gardens, acres of wetlands and meadows and a waterfront all within a 10 minute walk. There is also an indoor and outdoor shopping mall nearby. The new $40,000 \mathrm{~m}^{2} 15$ floor building is purpose-built and designed according to Active Design 2010 guidelines [34] to encourage more daily physical activity in the workplace; increase activity-based working and improve social interaction between the workers. New building features include an open central staircase, lifts separated from the stairs, abundant natural light, greater number of break out areas with standing tables as well as seats, a range of quiet workspaces and WIFI capability. All desks are height adjustable sit-stand desks, with a strictly enforced hot-desking and clear desk policy. To foster movement and interaction within the building and more broadly agile working, in which workers have some flexibility in deciding how and where they want to work, a new Ways of Working directive was introduced. Tables 1 and 2 show the key changes introduced to encourage more physical movement and interaction.

\subsection{Participants}

All 3924 workers relocating were invited to take part in the evaluation which involved surveys, accelerometers, blood pressure assessments, organisational sickness absence records, building audit and interviews (interviews will be reported elsewhere). The purpose of the study and the opportunity to take part in one or more of its research strands was advertised on the intranet in March and again in October 2018 by the regulatory agency's corporate communications team. Those interested in participating in the providing blood pressure assessments including the accelerometer study, contacted the project researcher directly who then sent the participant further details and a consent form and arranged a time 
to collect blood pressure measurements and accelerometery data. Participants were consented at pre move to also take part in post-move data collection. To take part in the survey, potential participants clicked on a survey link (OnlineSurveys) in the intranet article. The link took the participant to a secured online survey website which outlined further information about the purpose of the survey and provided a box to tick for consent. Participants then proceeded to complete the survey. Those who fully completed the survey were entered into a prize draw for $£ 200$ vouchers.

\subsection{Measures}

\subsubsection{Survey}

Survey questions assessed physical activity by one-item 'in a typical week, on how many days do you undertake 30 minutes or more of physical activity, enough to raise your breathing rate? [35]. Walking was measured by how much time (in hours and/or minutes) per day was spent commuting to work by walking and walking whilst at work. Sitting time was measured by how much time (in hours and/or minutes) per day was spent commuting to work by sitting and sitting whilst at work [36]. Stair use was assessed by asking participants to estimate how often they used the stairs on a typical workday. Participants were asked to separately estimate how many face-to-face interactions they have on a typical workday with colleagues within their teams, outside of their teams (excluding team meetings and interactions less than five minutes). Participants were asked to what extent they agreed or disagreed (7-point Likert scale), that the office design made it easier for unplanned workrelated interactions with colleagues, unplanned social interaction with colleagues, effective communication with team members, other teams and with their manager. They were also asked to what extent they agreed or disagreed that their manager supports and encourages them to use the various building workspaces and supports agile working (i.e. working from home). The survey also asked questions on satisfaction of work and building space (4 items, 
7-point Likert scale, total mean score), air quality (1 item), lighting, thermal and ambience (5 items, 7-point Likert scale, total mean score) [37], and satisfaction with access to outdoor spaces ( 1-item, 7-point Likert scale).

Work engagement was assessed by how energetic (vigor), enthusiastic (dedication) and immersed (absorption) participants were in their work [38]. Job satisfaction [39] and job performances [40] were assessed with one question each. Job control, job demands, and manager and peer job support were assessed using the Management Standards Indicator Tool (Health and Safety Executive, n.d.). Validated measures were used to assess musculoskeletal symptoms [41], mental well-being [42] and overall quality of health (EQ Visual Analogue Scale) [43]. Self-reported sickness absence was assessed by total number of workdays missed in the past three months due to sick leave. Information on age, gender, ethnicity, work hours, job contract, department and job role were also collected.

\subsubsection{Organisational Sickness Absence Records}

Six-months sickness absence data three months before and three months after the move from organisationally held records were accessed for those employees who gave permission via the survey.

\subsubsection{Blood Pressure and Accelerometery Data}

Arterial blood pressure was measured from the left arm in the sitting position using a semiautomated recorder (Omron Healthcare, Henfield, UK) in accordance with current recommendations [44]. Three assessments were taken by trained researchers with each measurement separated by a two-minute rest period and the mean systolic and diastolic blood pressures recorded from the second and third assessments were calculated. Physical 
activity and sedentary behavior was assessed using the activPAL3 micro device (accelerometer PAL Technologies, Glasgow, UK) which provides a valid measure of sitting, standing and stepping time $[45,46]$. The activPAL3 was waterproofed (using a nitrile sleeve and hypoallergenic Hypafix [BSN Medical] dressing) and participants were requested to wear the device continuously ( 24 hours/day) for 7 days on the anterior aspect of their nondominant thigh. The device was attached to the thigh using Hypafix dressing. Participants were provided with a brief log during each monitoring period in which they were requested to document time in bed, start and end times of work, and any periods of non-wear. The same participants provided blood pressure and activPAL data at post-move data collection

All activPALs were initialised and downloaded using manufacturer proprietary software (activPAL Professional v.7.2.32) and data were processed using the freely available ProcessingPAL Software (https://github.com/UOL-COLS/ProcessingPAL, version 1.1, University of Leicester, (Leicester UK)), which removes sleep time and any periods of nonwear [47]. Once time in bed and non-wear were excluded, a day was considered valid if it consisted of $\geq 10$ hours of waking wear data, $<95 \%$ of time spent in any one behaviour (e.g., sitting, standing, or stepping) and $\geq 500$ single leg steps (i.e., $\geq 1000$ steps) [47]. To be included in the analyses, participants were required to have provided $>3$ valid days of activPAL data on workdays both pre and post move. For the purposes of the present analyses, data collected during non-working days and non-working time were excluded (using participant log data). Average minutes spent sitting, standing and stepping, along with sit-to-stand transitions during work hours were calculated using the algorithm.

\subsection{Statistical Analysis}

\subsubsection{Sample size}


For blood pressure and accelerometer data, an a priori sample calculation analysis on $\mathrm{G}$ Power (version 3) [48], for a paired sample t-test was conducted. With a power of 0.90 and a two-way alpha level of 0.05 , and an assumed medium effect of $d=0.05,44$ participants were required to observe a statistical meaningful effect in our outcomes. To account for attrition, 60 participants were recruited. No formal sample size was calculated for the survey data and sickness absence data.

\subsubsection{Data Analyses}

Data were analysed using IBM Statistical Software for Social Sciences (SPSS) Version 26. $600(15 \%$ of the organisation) participants completed the baseline survey and $767(20 \%)$ completed the post-move survey. Of these participants, 221 (38\%) complete matched cases were available for analysis (matched on participant's self-created unique identifier code). Objectively measured sickness absence data were missing at random for 94 participants due to unwillingness to consent and were therefore multiple imputation was adopted [49].

The study hypotheses were tested using mixed model linear regression [50]. In all models, Time (pre-post move) (Level 1) was nested within each participant's ID (Level 2). To examine the interclass correlation coefficient (ICC) a variance-only model (model 1) was constructed. Following this, fixed predictors of time (pre-post) were entered into the model (model 2), with random-slopes for individual participants (model 3). Finally, age, gender, work hours, department and job role were entered into the model (model 4). Data were estimated using maximum likelihood and model fit was calculated through ${ }^{*}$ loglikelihood and $X^{2}$ distribution tests for significance. In all analysis, $p<.05$ was considered statistically significant. Each model met the assumptions associated with linear mixed modelling. Data are represented as mean and standard deviation. Paired-sample t-tests were conducted to 
test differences in systolic and diastolic blood pressure, sitting, standing and stepping time, and sit-to-stand transition times between pre and post-move.

\section{Results}

Two hundred and twenty-one employees (91.9\% on a permanent contract) aged between 23 and $65(40.10 \pm 9.94)$ years of which $63.8 \%$ female, were included in the survey analyses. All departments were represented in the sample. Sixty participants volunteered for the health assessment and accelerometery data from which 54 provided pre- and post-blood pressure measurements and 50 participants provided at least 3 valid workdays of pre and post activPAL data. Participant characteristics are presented in Table 3.

Results from the multi-level modelling are presented in Table 4. Following the move, participants reported spending significantly less time sitting per-day (-20.65 minutes, $p=0.001)$, and more time walking to work $(+9.54$ minutes, $p=0.001)$ and at work $(+5.61$ minutes, $p=0.001$ ). Results from the activPAL data also support hypothesis 2 (Table 5). Post-move, participant had significantly less occupational sitting time (-31.0 mins/workday, $p=0.04)$, more standing $(+22.0$ mins/workday, $p=0.02)$, and stepping time $(+11.0$ mins/workday, $p=0.001)$. However, participants spent significantly more time sat per-day in their commute $(+8.66$ mins/workday, $p=0.005)$, and stair use decreased $(-1.07, p=0.001)$ following the move to the new building. There were no meaningful improvements in amount of days of physical activity. Respondents reported that the larger office space and layout contributed to increased interactions with team members $(+1.06$ interactions, $p=0.001)$ and easier unplanned social interactions with colleagues $(+0.91, p=0.001)$, easier communication with other teams $(+0.69, p=0.001)$, improved manager support for agile working $(+0.29$, $p=0.001)$ and encouragement to use building facilities and space $(+0.68, p=0.001)$. No significant changes were observed for easier communication with team members or 
manager, nor in having unplanned work-related interactions with colleagues. Perceptions of air quality $(+0.81, p=0.001)$, satisfaction with lighting, thermal and ambience satisfaction $(+0.50, p=0.001)$ and with building space $(+1.42, p=0.001)$ significantly improved post-move.

Confirming hypothesis 2 , at post-move participants mental health and wellbeing significantly improved $(+0.53)(p=0.02)$ and reported significant reductions in musculoskeletal complaints for lower back $(-1.27, P=0.001)$, lower extremities $(-0.98, p=0.001)$ and upper extremities (1.18, $p=0.001)$. No meaningful effects were observed for neck and upper back musculoskeletal complaints or in overall quality of health. Results from blood pressure measurements also support hypothesis 2 (Table 5). Post-move, participant had significantly lower systolic $(-4.72 \mathrm{~mm} \mathrm{Hg}, p=0.003)$, and diastolic $(-3.57 \mathrm{~mm} \mathrm{Hg}, p=<0.001)$ blood pressure.

Confirming our third hypotheses (Table 4), participants' work vigor improved significantly $(+0.31, p=0.001)$ post-move. Conversely, participants perceived their job performance to significantly decrease $(-0.16, p=0.04)$ following the move. There were no statistically meaningful effects in job satisfaction, work absorption and dedication, job control, job demands, work-related support and self-reported or objectively measured sickness absence.

\section{Discussion}

This study focused on the impact of a new workplace built using active workplace design features on workers' sedentary behaviour, workplace interactions and physical and mental health. To our knowledge, this is one of the first studies to evaluate a relocation to a building with not only active design features but also how the organisation implemented change though its use of a new Ways of Working directive to encourage both movement and 
interaction within the building and to encourage the use of the outside open spaces and facilities.

Applying the ecological model to our results, our study found beneficial impacts on reduced sitting and increased walking at work post move thus supporting hypotheses 1 . These selfreport findings are supported by the accelerometery data with an average of 31 minutes reduction in workplace sitting time per day, and an increase in standing time by 22 minutes and stepping time by 11 minutes per day post move. These findings are notable, and support Engelen et al. [17] self-report findings and the objectively measured findings of Gorman et al. [51] and Jancey et al [52] but not those of Foley et al. [53], Elyer et al. [54] and Hallman et al. [55] who found no reduction in sitting time as measured by the activPAL. However, the differences between these latter three studies and our study is the lack of a control group in our study, which may account for the different results. Further differences could be accounted for by the built environment itself and the new Ways of Working directive (policy level). For example, the increase in the number of break out spaces, the introduction of sit-stand desks for all staff and the new hybrid laptops allowing workers to not be chained to a desk. Coupled with the social/cultural environment, whereby the new Ways of Working directive encourages workers to move around by actively asking managers to support their teams using the different building spaces (e.g. break out spaces, quiet spaces) and in agile working. Both of these latter points were found to have significantly increased post move, thus reflecting increase in the behavioural autonomy of workers to move around more and use the spaces available to them. A study by Sugiyama et al. [56] based on an RCT of a sitstand desk intervention, found participants who perceived sufficient informal discussion space and reported more-supportive organizational norms had lower levels of sitting time. As Sugiyama's study was based on an sit-stand desk intervention and perceptions of existing space and support, our study provides evidence for the impact of not just the 
introduction of sit-stand desks, but also the impact of increased spaces and changes in organisational policies and social/cultural norms for sitting less, standing and moving more.

The built environment, social/cultural environment and policy level changes may have also resulted in an increase in interactions between team members and colleagues including unplanned social interactions and align with previous findings $[15,57]$ supporting our hypotheses 1 . Our findings contribute to the emerging evidence that buildings with active design features have positive effects on communication and interactions [18].

Contrary to our hypotheses 1 , we found no significant difference in self-reported stair use or in physical activity. The reduction in stair use could be explained by the increase in the number of lifts available in the new building and the larger floorplates both potentially reducing movement between floors. However, it could also be accounted for by the lack of motivational and educational messages to use the stairs which the previous building had displayed in their stairwells. Future studies should include direct observations of stair use and infrared motion tracking (electronic counts) of stairwell use [58].

Confirming hypothesis 2 , our study found participants rated their mental health higher and reported reductions in some types of musculoskeletal complaints post-move. Results from blood pressure measurements also support hypothesis 2 . Reductions in systolic and diastolic blood pressure of $\geq 2 \mathrm{~mm} \mathrm{Hg}$ can significantly reduce the incidence of cardiovascular disease in both hypertensive and normotensive individuals, subsequently small reductions of this magnitude are considered clinically meaningful [59]. Overall, these results suggest that the active design features of the building, the new location and the new Ways of Working directive may have a positive effect on health. Our findings are novel as 
other similar natural intervention studies have found little impact. Engelen et al. [17] reported a reduction in lower back pain only, and no difference for mental health. Bergstrom [60] found no effects at all in their longitudinal study.

One of the most consistent findings from user surveys is that office workers are dissatisfied with the 'open plan' office, whether this is due to noise levels, distractions, and/or lack of privacy $[61,62]$. In our study, open plan offices were retained rather than introduced may explain the positive rather than negative results on physical and mental health. Furthermore, in the present study, participants were highly satisfied with the overall open workspaces provided in the new building as well as the access to outdoor spaces and together with reducing sitting and increased walking these factors may have all influenced workers physical and mental health. Evidence from sit-stand intervention studies provide some support for this suggestion [63]. Few have measured physical and mental health in their studies and a recent review found the evidence to be unclear [18]. Our study contributes to this area of research and shows that the built environment, social/cultural environment and the organisational policies around sitting less and interacting more, can together have a positive impact on health and wellbeing.

Confirming our third hypothesis, workers had increased work-related vigor (a component of work engagement) post-move. Increased work-related vigor or vitality has been reported in other studies $[13,64]$, and as it is considered to be an active, positive state, it may be associated with the decrease in sitting and increases in standing and stepping, as workers are breaking up their sitting time and moving around [13]. Contrary to the hypotheses, perceived job performance decreased and there were no significant findings in job satisfaction, work absorption and dedication, job control, job demands, work-related support and self-reported or objectively measured sickness absence post move. Other studies have 
also found a decrease in job performance following a move to a building with active design features $[17,60]$. It could be that post move assessments at two months is not long for adapting to change [60] and longer assessment periods are needed. Likewise, this may also be the case for job satisfaction and for sickness absence, and for the latter, the recording period (three months) may be too short to see any meaningful effects.

\subsection{Ecological model}

Our assessment of the way the agency implemented change suggests that they understood and targeted four levels of the socio-ecological model: policy/organisational level, built environment, social/cultural environment through their re-location and the introduction of the new Ways of Working directive (Tables 1 and 2). Whilst the agency did consult with their workers and set up representatives (move makers) from each team, the individual level of the model was not targeted in any training or educational or persuasive messages in the benefits of more movement and interaction. Furthermore, no evidence-based behaviour change techniques were encouraged among workers such as action planning, goal setting and self-monitoring standing and moving more [65]. Our results suggest that whilst changes were observed in sitting less, standing and moving more and an increase in some types of interaction, it is possible more differences may have been observed if the agency had included targeting change at the individual level [63]. Nevertheless, the study shows how targeting policy/organisational level, built environment and social/cultural environment without targeting the individual level can produce behaviour change and contributes the evidence from workplace communities to that of other research [33] that has found the individual level less important in producing behaviour change. Further research is required to examine whether these changes are sustainable without targeting at the individual level. More research is also required to investigate the knowledge and attitudes organisations 
have about implementing behaviour change strategies at the individual level when relocating.

\subsection{Strengths and Limitations}

The present study has several strengths. While addressing a natural intervention, our study employed a prospective pre and post measures design with the same sample of office workers within a single organization. Another strength of the study was the multiple methodologies used to collect data. Objectively measured sitting, standing and stepping time through accelerometers strengthened our self-reported findings. A further strength is the use of the ecological model to guide our data collection. However, in our study, no individual level strategies (e.g. goal setting, self-monitoring) were introduced by the organisation to support the workers' move and engagement with the new Ways of Working directive. This may have further strengthened our use of the model. However, a review on workplace approaches to reduce sitting reported that interventions focusing on individual-level strategies often show small effects, whereas those that include environmental interventions typically generate greater reductions in sitting time [66]. Other limitations include the low response rate to our survey at both times and of which only 221 participants could be linked with their pre and post survey responses. With regard to our health assessment and accelerometery data, there may have been a self-selection bias and those who agreed to participate may have been different from the group who did not volunteer to participate. Our findings should therefore be interpreted with caution.

\section{Conclusions}

The results of the present study demonstrate that relocating to a new workplace built with active workplace design features can have some health promoting effects, a positive impact 
on some types of interactions and change worker perceptions of the workplace. Future studies should examine how the different levels of the socio-ecological model interact to impact on employee health and wellbeing, and job related outcomes in an organisational change toward an active workplace design. Further longer-term research is needed that explores and examines the assumed underlying mechanisms of change and their effect on well-being, attitudinal and performance-related outcomes at each level.

Acknowledgements: This research was funded by the Regulatory Agency under research. The funding body was not involved in the study design, collection, analyses or interpretation of the data, or in the decision to submit the article for publication.

The research was supported by the National Institute for Health Research (NIHR) Leicester Biomedical Research Centre which is a partnership between University Hospitals of Leicester NHS Trust, Loughborough University and the University of Leicester, the National Institute for Health Research Collaboration for Leadership in Applied Health Research and Care-East Midlands (NIHR CLAHRC-EM), and the Leicester Clinical Trials Unit. The views expressed are those of the authors and not necessarily those of the NHS, NIHR, or Department of Health.

\section{Declaration of Conflicting Interests}

The author(s) disclose receipt of the following financial support for the research, authorship, and/or publication of this article: This research was funded by the Regulatory Agency under research. 
EVALUATION OF A NEW WORKPLACE WITH ACTIVE DESIGN FEATURES

\section{References}

[1] Engelen L, Chau J, Bohn-Goldbaum E, Young S, Hespe D. Bauman A. Is Active Design changing the workplace? - A natural pre-post experiment looking at health behaviour and workplace perceptions. Work. 2017; 56: 229-237. https://doi.org/10.3233/WOR-172483

[2] Candido C, Thomas L, Haddad S, Zhang F, Mackey M, Ye W. Designing activity-based workspaces: satisfaction, productivity and physical activity. Build Res Infor. 2019; 47(3):27589. https://doi.org/10.1080/09613218.2018.1476372

[3] Engelen L. Does Active Design Influence Activity, Sitting, Wellbeing and Productivity in the Workplace? A Systematic Review. Int J Environ Res Pub Health. 2020; 24:9228. https://doi.org/10.3390/ijerph17249228

[4] Prince SA, Roberts KC, Reed JL, Biswas A, Colley RC, and Thompson W. Daily Physical Activity and Sedentary Behaviour across Occupational Classifications in Canadian Adults. Health Rep. 2020;31(9):13-26.

[5] Healy GN, Eakin EG, Lamontagne AD, Owen N, Winkler EA, Wiesner G, Gunning L, Neuhaus M, Lawler S, Fjeldsoe BS, Dunstan DW. Reducing sitting time in office workers: short-term efficacy of a multicomponent intervention. Prev. Med. 57 (2013) 43-48. https://doi.org/10.1016/j.ypmed.2013.04.004

[6] Thorp AA, Owen N, Neuhaus M, Dunstan DW. Sedentary behaviors and subsequent health outcomes in adults a systematic review of longitudinal studies 1996-2011. Am J Prev Med. 2011; 41: 207-15. https://doi.org/10.1016/j.amepre.2011.05.004 


\section{EVALUATION OF A NEW WORKPLACE WITH ACTIVE DESIGN FEATURES}

[7] Saunders TJ, Mclsaac T, Douillette K, Gaulton N, Hunter S, Rhodes RE, Prince SA, Carson V, Chaput JP, Chastin S, Giangregorio L. Sedentary behaviour and health in adults: an overview of systematic reviews. Appl Phys, Nutr Metab. 2020; 45(10):S197217. https://doi.org/10.1139/apnm-2020-0272

[8] Janssen I, Clarke AE, Carson V, Chaput JP, Giangregorio LM, Kho ME, Poitras VJ, Ross R, Saunders TJ, Ross-White A, Chastin SF. A systematic review of compositional data analysis studies examining associations between sleep, sedentary behaviour, and physical activity with health outcomes in adults. Appl Phys, Nutr Metab. 2020;45(10):S248-57. https://doi.org/10.1139/apnm-2020-0160

[9] Teychenne M, Costigan SA, Parker K. The association between sedentary behaviour and risk of anxiety: a systematic review. BMC Pub Health. 2015; 15: 513. https:/doi.org/10.1186/s12889-015-1843-x

[10] Huang Y, Li L, Gan Y, Wang C, Jiang H, Cao S, Lu Z. Sedentary behaviors and risk of depression: a meta-analysis of prospective studies. Trans Psych. 2020; 22;10(1):1-0. https://doi.org/10.1038/s41398-020-0715-z

[11] Hallman DM, Gupta N, Mathiassen SE, Holtermann A. Association between objectively measured sitting time and neck-shoulder pain among blue-collar workers. Int Arch Occup Environ Health. 2015; 88: 1031-1042. https://doi/org/10.1007/s00420-015-1031-4

[12] Puig-Ribera A, Martínez-Lemos I, Giné-Garriga M, González-Suárez ÁM, Bort-Roig J, Fortuño J, Munoz-Ortiz M, McKenna J, Gilson ND. Self-reported sitting time and physical activity: interactive associations with mental well-being and productivity in office employees. BMC Pub Health. 2015; 15: 72. https://doi/org/10.1186/s12889-015-1447-5 


\section{EVALUATION OF A NEW WORKPLACE WITH ACTIVE DESIGN FEATURES}

[13] Munir F, Houdmont J, Clemes S, Wilson K, Kerr R, Addley, K. Work engagement and its association with occupational sitting time: results from the Stormont study. BMC Public Health. 2015; 15: 30. https:/doi.org/10.1186/s12889-015-1427-9

[14] Puig-Ribera A, Bort-Roig J, Giné-Garriga M, González-Suárez AM, Martínez-Lemos I, Fortuño J, Martori JC, Muñoz-Ortiz L, Milà R, Gilson ND, McKenna J. Impact of a workplace 'sit less, move more'program on efficiency-related outcomes of office employees. BMC Pub Health. 2017; 17(1):1-1. https://doi.org/10.1186/s12889-017-4367-8

[15] Candido C, Thomas L, Haddad S, Zhang F, Mackey M, Ye W. Designing activity-based workspaces: satisfaction, productivity and physical activity. Build Res Inf. 2019; 47: 275-289. https://doi.org/10.1080/09613218.2018.1476372

[16] Sugiyama T, Winkler EA, LaMontagne AD, Healy GN, Hadgraft NT, Dunstan DW, Owen N. Associations of device-measured sitting, standing, and stepping time with informal faceto-face interactions at work. J Occup Environ Med. 2019; 61(5):431-6. doi:

\section{$\underline{10.1097 / J O M .0000000000001586}$}

[17] Engelen L, Chau J, Bohn-Goldbaum E, Young S, Hespe D, Bauman A. Is Active Design changing the workplace? - A natural pre-post experiment looking at health behaviour and workplace perceptions. Work. 2017; 56: 229-237. https://doi.org/10.3233/WOR-172483

[18] Engelen L, Chau J, Young S, Mackey M, Jeyapalan D, Bauman A. Is activity-based working impacting health, work performance and perceptions? A systematic review. Build Res Inf. 2018; 47: 468-479. https://doi.org/10.1080/09613218.2018.1440958 
EVALUATION OF A NEW WORKPLACE WITH ACTIVE DESIGN FEATURES

[19] Colenberg S, Jylhä T, Arkesteijn M. The relationship between interior office space and employee health and well-being-a literature review. Build Res Infor. 2020; 17:1-5. https://doi.org/10.1080/09613218.2019.1710098

[20] Heinzerling D, Schiavon S, Webster T, Arens E. Indoor environmental quality assessment models: A literature review and a proposed weighting and classification scheme. Build Environ. 2013; 70: 210-222. https://doi.org/10.1016/j.buildenv.2013.08.027

[21] Lamb S, Kwok KCS. A longitudinal investigation of work environment stressors on the performance and wellbeing of office workers. Appl Ergon. 2016; 52: 104-111. https://doi.org/10.1016/i.apergo.2015.07.010

[22] Candido C, Marzban S, Haddad S, Mackey M, Loder A. Designing healthy workspaces: Results from Australian certified open-plan offices. Facilities. 2020; ahead of print https://doi.org/10.1108/F-02-2020-0018

[23] Elsbach KD, Pratt MG. The physical environment in organizations. The Acad. Manage. Ann. 2007; 1: 181-224. https://doi.org/http://dx.doi.org/10.1080/078559809

[24] Wohlers C, Hertel G. Choosing where to work at work-towards a theoretical model of benefits and risks of activity-based flexible offices. Ergon. 2017; 60: 467-486. https://doi.org/10.1080/00140139.2016.1188220

[25] Morrison RL, Macky KA. The demands and resources arising from shared office spaces. Appl Ergon. 2017; 60:103-15. https://doi.org/10.1016/j.apergo.2016.11.007 


\section{EVALUATION OF A NEW WORKPLACE WITH ACTIVE DESIGN FEATURES}

[26] Ayoko OB, Ashkanasy NM. The physical environment of office work: Future open plan offices. Australian Journal of Management. 2020 Aug;45(3):488-506.

https://doi.org/10.1177/0312896220921913

[27] Marquet O, Floyd MF, James P, Glanz K, Jennings V, Jankowska MM, Kerr J, Hipp JA. Associations between worksite walkability, greenness, and physical activity around work. Environ Behav. 2018; 52: 139-163. https://doi.org/10.1177/0013916518797165

[28] Forsyth A. What is a walkable place? The walkability debate in urban design, Urban Des Int. 2015; 20: 274-292. https:/doi.org/10.1057/udi.2015.22

[29] Foley L, Panter J, Heinen E, Prins R, Ogilvie D. Changes in active commuting and changes in physical activity in adults: A cohort study. Int J Behav Nutr Phys Activ. 2015; 12 : 161. https://doi.org/10.1186/s12966-015-0323-0

[30] Lin CY, Koohsari MJ, Liao Y, Ishii K, Shibata A, Nakaya T, McCormack GR, Hadgraft N, Owen N, Oka K. Workplace neighbourhood built environment and workers' physically-active and sedentary behaviour: a systematic review of observational studies. Int J Behav Nutr Phys Act. 2020; 17(1):1-24. https://doi.org/10.1186/s12966-020-01055-x

[31] Sallis JF, Floyd MF, Rodríguez DA, Saelens BE. Role of built environments in physical activity, obesity, and cardiovascular disease. Circulation. 2012; 7: 729-37.

https://doi.org/10.1161/CIRCULATIONAHA.110.969022

[32] Sallis J, Owen N. Ecological models of health behavior. In Glanz K, Rimer B, Viswanath K, editors. Health behavior: Theory, research, and practice. Jossey-Bass, 2015, 43-64. 


\section{EVALUATION OF A NEW WORKPLACE WITH ACTIVE DESIGN FEATURES}

[33] Schilling JM, Giles-Corti B, Sallis JF. Connecting active living research and public policy: Transdisciplinary research and policy interventions to increase physical activity. J Pub Health Policy. 2009; 30(Suppl. 1): S1- S15. https://doi.org/10.1057/jphp.2008.59

[34] American Active Design guidelines NYC. https://centerforactivedesign.org/guidelines/ 2010 (Accessed 20 $0^{\text {th }}$ April 2020)

[35] Milton K, Clemes S, Bull F. Can a single question provide an accurate measure of physical activity? Br J Sports Med. 2013; 47(1): 44-48. https://doi.org/10.1136/bjsports-2011$\underline{090899}$

[36] Marshall AL, Miller YD, Burton NW, Brown WJ. Measuring total and domain specific sitting: a study of reliability and validity. Med Sci Sports Exerc. 2010; 42: 1094-102. https://doi.org/ 10.1249/MSS.0b013e3181c5ec18

[37] Candido C, Kim J, de Dear R, Thomas L, BOSSA: a multidimensional post-occupancy evaluation tool. Build Res Inf. 2016; 44: 214-228. https://doi.org/10.1080/09613218.2015.1072298

[38] Schaufeli WB, Shimazu A, Hakanen J, Salanova M, De Witte H. An ultra-short measure for work engagement: The UWES-3 validation across five countries. Eur J Psychol Assess. 2019; 35: 577-591. https://doi.org/10.1027/1015-5759/a000430

[39] Nagy MS. Using a single-time approach to measure facet job satisfaction. J Occup Org Psychol. 2002; 75: 77-86. https://doi.org/10.1348/096317902167658 


\section{EVALUATION OF A NEW WORKPLACE WITH ACTIVE DESIGN FEATURES}

[40] Bond FW, Bunce D. Job control mediates change in a work reorganization intervention for stress reduction. J Occup Health Psychol. 2001; 6: 290-302. https://doi:10.1037/1076$\underline{8998.6 .4 .290}$

[41] Kuorinka I, Jonsson B, Kilbom A, Vinterberg H, Biering-Sørensen F, Andersson G, Jørgensen K. Standardised Nordic questionnaires for the analysis of musculoskeletal symptoms. Appl Ergon. 1987; 18: 233-237. https://doi.org/10.1016/0003-6870(87)90010-X

[42] Maheswaran H, Weich S, Powell J, Stewart-Brown S. Evaluating the responsiveness of the Warwick Edinburgh Mental Well-Being Scale (WEMWBS): Group and individual level analysis. Health Qual Life Outcomes. 2012; 10: 156. https://doi.org/10.1186/1477-7525-10$\underline{156}$

[43] The EuroQol Group EuroQol-a new facility for the measurement of health-related quality of life. Health Policy. 1990; 16: 199-208.

[44] O'Brien E, Asmar R, Beilin L, Imai Y, Mallion JM, Mancia G, Mengden T, Myers M, Padfield P, Palatini P, Parati G, Pickering T, Redon J, Staessen J, Stergiou G, Verdecchia P, European Society of Hypertension Working Group on Blood Pressure Monitoring. European Society of Hypertension recommendations for conventional, ambulatory and home blood pressure measurement. J. Hypertens. 2003; 21: 821-848. https://doi.org/10.1097/00004872$\underline{200305000-00001}$

[45] Ryan CG, Grant PM, Tigbe WW, Granat MH. The validity and reliability of a novel activity monitor as a measure of walking. Br J Sports Med. 2006; 40: 779-84. 


\section{EVALUATION OF A NEW WORKPLACE WITH ACTIVE DESIGN FEATURES}

[46] Kozey-Keadle S, Libertine A, Lyden K, Staudenmayer J, Freedson PS. Validation of wearable monitors for assessing sedentary behavior. Med Sci Sports Exerc. 2011; 43: 15611567. https://doi.org/10.1249/MSS.0b013e31820ce174

[47] Winkler EA, Bodicoat DH, Healy GN, Bakrania K, Yates T, Owen N, Dunstan DW, Edwardson CL. Identifying adults' valid waking wear time by automated estimation in activPAL data collected with a 24 h wear protocol. Phys Measurement. 2016; 37: 1653-1668.

[48] Faul F, Erdfelder E, Lang A.-G, Buchner A, G*Power 3: A flexible statistical power analysis program for the social, behavioral, and biomedical sciences. Behav Res Meth. 2007; 39: 175-191.

[49] Horton NJ, Kleinman KP. Much ado about nothing: A comparison of missing data methods and software to fit incomplete data regression models. The Am Stat. 2012; 61: 7990. https://doi.org/10.1198/00031300\&X172556

[50] West BT. Analysing longitudinal data with the linear mixed model procedure in SPSS. Eval Health Prof. 2009; 32: 207-228. https://doi.org/10.1177/0163278709338554.

[51] Gorman E, Ashe MC, Dunstan DW, Hanson HM, Madden K, Winkler EA, McKay HA, Healy GN. Does an "activity-permissive" workplace change office workers' sitting and activity time? PLoS ONE. 2013; 8: e76723. https:/doi.org/10.1371/journal.pone.0076723

[52] Jancey JM, McGann S, Creagh R, Blackford KD, Howat P, Tye M. Workplace building design and office-based workers' activity: A study of a natural experiment. Aust New Z J Pub Health. 2016; 40: 78-82. https://doi.org/10.1111/1753-6405.12464 
EVALUATION OF A NEW WORKPLACE WITH ACTIVE DESIGN FEATURES

[53] Foley B, Engelen L, Gale J, Bauman A, Mackey M. Sedentary behavior and musculoskeletal discomfort are reduced when office workers trial an activity-based work environment. J Occup Environ Med. 2016; 58: 924-931. http://dx.doi.org/10. 1097/jom.0000000000000828

[54] Eyler AA, Hipp A, Valko CA, Ramadas R, Zwald M. Can Building Design Impact Physical Activity? A Natural Experiment. J Phys Activ Health. 2018; 15: 355-360. https://doi.org/10.1123/jpah.2017-0319

[55] Hallman DM, Mathiassen SE, Jahncke $\mathrm{H}$, Sitting patterns after relocation to activitybased offices: A controlled study of a natural intervention. Prev Med. 2018; 111: 384-390. https://doi.org/10.1016/j.ypmed.2017.11.031

[56] Sugiyama T, Hadgraft NT, Healy GN, Owen N, Dunstan DW. Perceived Availability of Office Shared Spaces and Workplace Sitting: Moderation by Organizational Norms and Behavior. Auton Environ Behav. 2018; 51: 856-878.

https://doi.org/10.1177/0013916518772014

[57] Mullane SL, Toledo MJ, Rydell SA, Feltes LH, Vuong B, Crespo NC, Pereira MA, Buman MP. Social ecological correlates of workplace sedentary behavior. Int J Behav Nutr Phys Act. 2017; 14(1):1-0. https://doi.org/10.1186/s12966-017-0576-x

[58] Moloughney BW, Bursey GE, Fortin RB, Morais MG, Dang KT. A multicomponent intervention to encourage stair use in municipal buildings. Am J Health Promot. 2019; 33: 57-69. https://doi.org/10.1177/0890117118776893 
EVALUATION OF A NEW WORKPLACE WITH ACTIVE DESIGN FEATURES

[59] Wong GW, Wright JM. Blood pressure lowering efficacy of nonselective beta-blockers for primary hypertension. Cochrane Database Syst. Rev. 2014: 28: CD007452. https://doi.org/10.1002/14651858

[60] Bergström J, Miller M, Horneij E. Work environment perceptions following relocation to open-plan offices: A twelve-month longitudinal study. Work. 2015; 50: 221-228. https://doi.org/10.3233/WOR-131798

[61] Morrison RL, Macky KA. The demands and resources arising from shared office spaces. Appl Ergon. 2017; 60: 103-115. https://doi.org/10.1016/j.apergo.2016.11.007

[62] Chen CF, Yilmaz S, Pisello AL, De Simone M, Kim A, Hong T, Bandurski K, Bavaresco MV, Liu PL, Zhu Y. The impacts of building characteristics, social psychological and cultural factors on indoor environment quality productivity belief. Build Environ. 2020;185: 107189. https://doi.org/10.1016/j.buildenv.2020.107189

[63] Edwardson CL, Yates T, Biddle SJH, Davies MJ, Dunstan D, Esliger D, Gray LJ, Jackson BR, O-Connell SE, Waheed G, Munir F. The effectiveness of the Stand More AT (SMArT) Work intervention: A cluster randomised controlled trial. BMJ; 2018; 363. https://doi.org/10.1136/bmj.k3870

[64] Wohlers C, Hartner-Tiefenthaler M, Hertel G. The Relation Between Activity-Based Work Environments and Office Workers' Job Attitudes and Vitality. Environ Behav. 2019; 51: 167-198. https://doi.org/10.1177/0013916517738078

[65] Gardner B, Smith L, Lorencatto F, Hamer M, Biddle SJ. How to reduce sitting time? A review of behaviour change strategies used in sedentary behaviour reduction interventions 
EVALUATION OF A NEW WORKPLACE WITH ACTIVE DESIGN FEATURES

among adults. Health Psychol Rev. 2016; 10: 89-112.

https://doi.org/10.1080/17437199.2015.1082146

[66] Chu AHY, Ng SHX, Tan CS, Win AM, Koh D. Muller-Riemenschneider, F. A systematic review and meta-analysis of workplace intervention strategies to reduce sedentary time in white-collar workers. Obes. Rev. 2016; 17: 467- 481. https://doi.org/10.1111/obr.12388

[67] Oldenburg B, Sallis J, Harris D, Owen N. Checklist of Health Promotion Environments at Worksites (CHEW): Development and Measurement Characteristics. Am J Health Promot. 2002; 16: 188-199. 
Table 1: Building relocation and key changes for staff

\begin{tabular}{|c|c|c|c|}
\hline $\begin{array}{l}\text { What has } \\
\text { changed? }\end{array}$ & $\begin{array}{l}\text { Written } \\
\text { Policy } \\
\text { Statement }\end{array}$ & Training & $\begin{array}{l}\text { Additional } \\
\text { communication / support }\end{array}$ \\
\hline \multicolumn{4}{|l|}{ Environmental } \\
\hline $\begin{array}{l}\text { Sit-stand desk for } \\
\text { each person }\end{array}$ & No & $\begin{array}{l}\text { Compulsory online } \\
\text { module on desk set- } \\
\text { up, which included } \\
\text { some information on } \\
\text { using sit-stand desks. }\end{array}$ & $\begin{array}{l}\text { Day one set up. Training by } \\
\text { ergonomic specialists. } \\
\text { Workplace adjustments } \\
\text { provider on site throughout } \\
\text { moves. }\end{array}$ \\
\hline $\begin{array}{l}\text { Two accessible, } \\
\text { open staircases }\end{array}$ & $\mathrm{N} / \mathrm{A}$ & $N / A$ & $\mathrm{~N} / \mathrm{A}$ \\
\hline $\begin{array}{l}\text { Improved gym space } \\
\text { (and classes) }\end{array}$ & $\mathrm{N} / \mathrm{A}$ & Yes. & Notice boards and intranet. \\
\hline \multicolumn{4}{|c|}{ Ways of Working directive } \\
\hline $\begin{array}{l}\text { Activity-based } \\
\text { working encouraged } \\
\text { in new building } \\
\text { space/ facilities. }\end{array}$ & $\begin{array}{l}\text { Guidance } \\
\text { on when to } \\
\text { use } \\
\text { different } \\
\text { spaces. }\end{array}$ & $\begin{array}{l}\text { Ways of Working } \\
\text { Teams facilitated } \\
\text { conversations in } \\
\text { groups. }\end{array}$ & $\begin{array}{l}\text { Day One induction on new } \\
\text { building for all workers. } \\
\text { Range of positive and } \\
\text { negative manager support } \\
\text { for space use. }\end{array}$ \\
\hline $\begin{array}{l}\text { Hot desking with } \\
\text { strict clear desk } \\
\text { policy }\end{array}$ & Yes & No & $\begin{array}{l}\text { Range of positive and } \\
\text { negative manager support } \\
\text { for day to day desk } \\
\text { relocation. }\end{array}$ \\
\hline $\begin{array}{l}\text { Hybrid laptops for all } \\
\text { workers with built-in } \\
\text { capability to allow } \\
\text { flexible use } \\
\text { throughout building. }\end{array}$ & Yes & $\begin{array}{l}\text { Yes from I.T. } \\
\text { department before } \\
\text { moving took place. }\end{array}$ & $\begin{array}{l}\text { Yes, bite-sized learning to } \\
\text { align with move schedule. }\end{array}$ \\
\hline $\begin{array}{l}\text { Flexible working } \\
\text { (e.g. hours / } \\
\text { location) } \\
\text { encouraged more } \\
\text { across board. }\end{array}$ & Yes & $\begin{array}{l}\text { Conversations within } \\
\text { departments, } \\
\text { facilitated by member } \\
\text { of Advanced Manager } \\
\text { or Future Manager } \\
\text { programmes. }\end{array}$ & $\begin{array}{l}\text { Annual review process } \\
\text { introduced and now } \\
\text { completed twice. } \\
\text { Some inconsistencies } \\
\text { between managers / } \\
\text { departments. }\end{array}$ \\
\hline
\end{tabular}


Table 2: Health promotional characteristics from the observational environmental audit*

\begin{tabular}{|c|c|c|}
\hline & $\begin{array}{l}\text { Old building }\left(34,000 \mathrm{~m}^{2}\right) \\
\text { and location } \\
\mathrm{N} / \text { Available }\end{array}$ & $\begin{array}{l}\text { New building }\left(40,000 \mathrm{~m}^{2}\right) \\
\text { and location } \\
\mathrm{N} / \text { Available }\end{array}$ \\
\hline \multicolumn{3}{|l|}{ PHYSICAL ENVIRONMENT } \\
\hline Stairwells & 2 & 1 \\
\hline Open staircases & 1 & 2 \\
\hline Lifts & 8 & 15 \\
\hline Gym & 1 (202.51Sqm) & 1 (505.5sqm) \\
\hline Bike racks & 78 & 173 \\
\hline Lockers & 100 & 274 \\
\hline Bike lanes on road & No & Yes \\
\hline Nearby fitness facilities & No & Yes \\
\hline Nearby swimming pool & No & Yes \\
\hline Nearby park/green open space & No & Yes \\
\hline \multicolumn{3}{|l|}{ INFORMATIONAL } \\
\hline \multicolumn{3}{|l|}{ ENVIRONMENT } \\
\hline Physical activity signs & 0 & 4 \\
\hline $\begin{array}{l}\text { Signs and notices promoting stair } \\
\text { use }\end{array}$ & 5 & 0 \\
\hline $\begin{array}{l}\text { Reducing sedentary behaviour } \\
\text { signs }\end{array}$ & 0 & 1 \\
\hline \multicolumn{3}{|l|}{$\begin{array}{l}\text { Other environmental health } \\
\text { promotion }\end{array}$} \\
\hline Height adjustable workstations & 1 & All staff \\
\hline Standing meeting rooms & 0 & 0 \\
\hline
\end{tabular}


Table 3: Pre move survey participant and health assessment/accelerometery data participants characteristics.

\begin{tabular}{|c|c|c|}
\hline Characteristics & $\begin{array}{l}\text { Survey } \\
\text { participants } \\
(n=221)\end{array}$ & $\begin{array}{l}\text { Health Assessment } \\
\text { and accelerometery } \\
\text { participants }(n=54)\end{array}$ \\
\hline \multicolumn{3}{|l|}{ Gender } \\
\hline Male & $80(36 \%)$ & $23(43 \%)$ \\
\hline Female & $138(62 \%)$ & $31(57 \%)$ \\
\hline \multicolumn{3}{|l|}{ Age } \\
\hline $18-27$ & $11(5 \%)$ & $0(0 \%)$ \\
\hline $28-37$ & $85(38 \%)$ & $20(37 \%)$ \\
\hline $38-47$ & $66(30 \%)$ & $13(24 \%)$ \\
\hline $58-67$ & $46(21 \%)$ & $11(20 \%)$ \\
\hline $68-77$ & $13(6 \%)$ & $7(13 \%)$ \\
\hline \multicolumn{3}{|l|}{ Ethnicity } \\
\hline White (British//rish/other) & $178(80 \%)$ & $40(78 \%)$ \\
\hline South Asian (e.g. Pakistani/Indian) & $21(9 \%)$ & $6(12 \%)$ \\
\hline Black (African/Caribbean/other) & $6(3 \%)$ & $1(2 \%)$ \\
\hline Other & $15(8 \%)$ & $4(8 \%)$ \\
\hline \multicolumn{3}{|l|}{ Job role } \\
\hline Manager & $54(24 \%)$ & $10(20 \%)$ \\
\hline Non-manager & $167(76 \%)$ & $80(80 \%)$ \\
\hline \multicolumn{3}{|l|}{ Length of employment } \\
\hline $0-12$ months & $19(9 \%)$ & $4(8 \%)$ \\
\hline 1 to 3 years & $45(20 \%)$ & $9(18 \%)$ \\
\hline 4 to 5 years & $66(30 \%)$ & $17(33 \%)$ \\
\hline 6 to 10 years & $141(19 \%)$ & $8(16 \%)$ \\
\hline 11 to 15 years & $26(12 \%)$ & $5(10 \%)$ \\
\hline
\end{tabular}


EVALUATION OF A NEW WORKPLACE WITH ACTIVE DESIGN FEATURES

16 or more years

$24(11 \%) \quad 8(16 \%)$

Job contract

Permanent

$203(2 \%)$

$30(94 \%)$

Contractual

$18(8 \%)$

$2(6 \%)$

Work hours mean (standard deviation))

$38.35(6.95)$

40.00 (8.04) 


\section{EVALUATION OF A NEW WORKPLACE WITH ACTIVE DESIGN FEATURES}

Table 4. Descriptive statistics and linear mixed model regression: survey findings pre-post move $(n=221)$

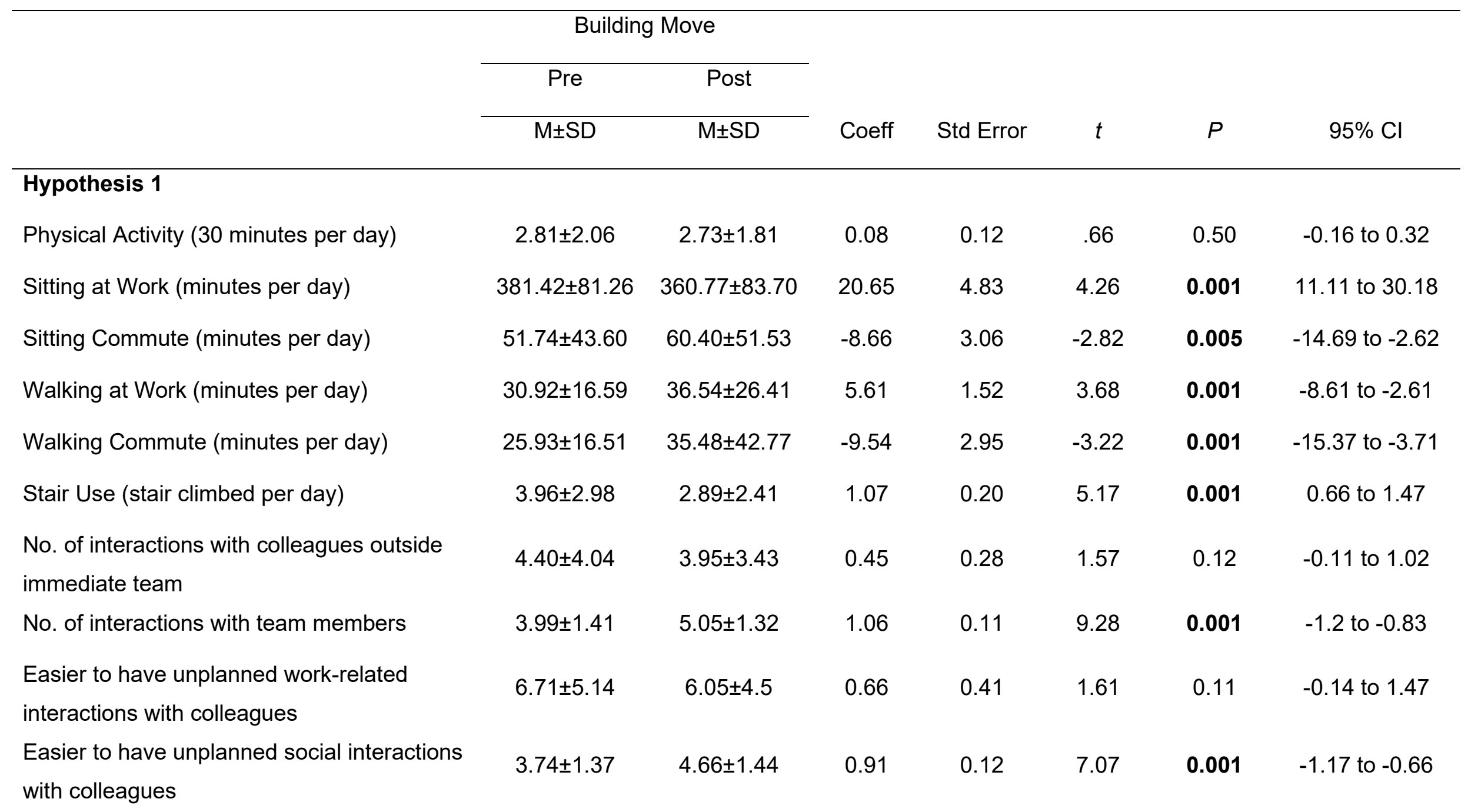


EVALUATION OF A NEW WORKPLACE WITH ACTIVE DESIGN FEATURES

\begin{tabular}{|c|c|c|c|c|c|c|c|}
\hline Easier communication with manager & $4.72 \pm 1.57$ & $4.96 \pm 1.51$ & 0.23 & 0.12 & 1.90 & 0.06 & -0.48 to 0.00 \\
\hline Easier communication with other teams & $4.21 \pm 1.50$ & $4.72 \pm 1.41$ & 0.69 & 0.12 & 5.60 & 0.001 & -0.94 to -0.45 \\
\hline Easier communication with team members & $4.70 \pm 1.52$ & $4.95 \pm 1.62$ & -0.24 & 0.13 & 1.83 & 0.07 & -0.50 to 0.18 \\
\hline $\begin{array}{l}\text { Manager encouragement to use building } \\
\text { spaces }\end{array}$ & $3.34 \pm 1.21$ & $3.63 \pm 1.19$ & 0.28 & 0.08 & .3 .35 & 0.001 & -0.45 to -0.11 \\
\hline Manager support for agile working & $2.60 \pm 1.17$ & $3.29 \pm 1.17$ & 0.68 & 0.09 & 7.62 & 0.001 & -0.86 to -0.51 \\
\hline Work and building space satisfaction & $3.52 \pm 1.13$ & $4.94 \pm 1.24$ & 1.41 & 0.10 & -13.90 & 0.001 & -1.62 to -1.21 \\
\hline Lighting, thermal and ambience satisfaction & $3.70 \pm 1.08$ & $4.20 \pm 1.29$ & 0.49 & 0.09 & 5.47 & 0.001 & -0.67 to -0.31 \\
\hline Air Quality satisfaction & $4.11 \pm 1.58$ & $4.92 \pm 1.55$ & 0.81 & 0.12 & -6.63 & 0.001 & -1.5 to -0.57 \\
\hline Access to outdoor space & $3.03 \pm 1.70$ & $5.30 \pm 1.64$ & 0.10 & 0.15 & -14.86 & 0.001 & -2.57 to -1.97 \\
\hline \multicolumn{8}{|l|}{ Hypothesis 2} \\
\hline Mental health & 21.343 .71 & $21.87 \pm 3.74$ & 0.52 & 0.23 & 2.27 & 0.02 & 0.69 to 0.98 \\
\hline Lower back pain & $4.02 \pm 3.19$ & $2.75 \pm 3.26$ & 1.27 & 0.19 & 6.38 & 0.001 & 0.88 to 1.66 \\
\hline Lower extremities pain (legs, ankles, feet) & $2.35 \pm 1.82$ & $1.36 \pm 1.90$ & 0.98 & 0.12 & 7.99 & 0.001 & 0.74 to 1.22 \\
\hline Neck and upper Back pain & $3.90 \pm 2.64$ & $3.82 \pm 4.02$ & 0.08 & 0.25 & .34 & 0.73 & -0.40 to 0.57 \\
\hline Upper extremities pain (Arms, wrists, hands) & $2.22 \pm 1.79$ & $1.04 \pm 1.64$ & 1.18 & 0.12 & 9.57 & 0.001 & 0.94 to 1.43 \\
\hline Overall quality of health & $73.43 \pm 18.13$ & $73.57 \pm 19.80$ & -0.14 & 1.47 & -.09 & 0.92 & -3.04 to 2.76 \\
\hline
\end{tabular}


Table 4 continued

\begin{tabular}{|c|c|c|c|c|c|c|c|}
\hline & \multicolumn{2}{|c|}{ Building Move } & Coeff & Std Error & $t$ & $P$ & $95 \% \mathrm{Cl}$ \\
\hline $\begin{array}{l}\text { Manager encouragement to use building } \\
\text { spaces }\end{array}$ & $3.34 \pm 1.21$ & $3.63 \pm 1.19$ & 0.28 & 0.08 & .3 .35 & 0.001 & -0.45 to -0.11 \\
\hline Manager support for agile working & $2.60 \pm 1.17$ & $3.29 \pm 1.17$ & 0.68 & 0.09 & 7.62 & 0.001 & -0.86 to -0.51 \\
\hline Job Satisfaction & $4.54 \pm 1.37$ & $4.59 \pm 1.49$ & -0.04 & 0.08 & -.53 & 0.59 & -0.21 to 0.12 \\
\hline Job Performance & $5.58 \pm .953$ & $5.42 \pm 1.14$ & 0.162 & 0.08 & 2.08 & 0.04 & 0.01 to 0.31 \\
\hline Work Engagement (Absorption) & $5.08 \pm 1.07$ & $5.17 \pm .98$ & -0.095 & 0.07 & -1.38 & 0.17 & -0.22 to 0.03 \\
\hline Self-Reported Sickness Absence & $3.37 \pm 7.02$ & $2.58 \pm 5.38$ & 0.79 & 0.55 & 1.43 & 0.15 & -0.29 to 1.88 \\
\hline Objectively-Measured Sickness Absence ${ }^{\dagger}$ & $1.60 \pm 2.90$ & $2.15 \pm 3.48$ & -0.53 & 0.35 & -1.49 & 0.14 & -1.24 to 0.17 \\
\hline
\end{tabular}

$P \leq .05$ is considered significant. ${ }^{\dagger} 94$ case of missing data (non-consenting) treated with multiple imputation. 
EVALUATION OF A NEW WORKPLACE WITH ACTIVE DESIGN FEATURES

Table 4. continued

\begin{tabular}{|c|c|c|c|c|c|c|c|}
\hline & \multicolumn{2}{|c|}{ Building Move } & \multirow[b]{3}{*}{ Coeff } & \multirow[b]{3}{*}{$\begin{array}{l}\text { Std } \\
\text { Error }\end{array}$} & \multirow[b]{3}{*}{$t$} & \multirow[b]{3}{*}{$P$} & \multirow[b]{3}{*}{$95 \% \mathrm{Cl}$} \\
\hline & Pre & Post & & & & & \\
\hline & $\mathrm{M} \pm \mathrm{SD}$ & $\mathrm{M} \pm \mathrm{SD}$ & & & & & \\
\hline Job control & $3.56 \pm .65$ & $3.61 \pm .57$ & -0.05 & 0.03 & -1.36 & 0.17 & $\begin{array}{c}-0.13 \text { to } \\
0.02\end{array}$ \\
\hline $\begin{array}{l}\text { Job demands (Reverse } \\
\text { Scored) }\end{array}$ & $3.11 \pm .68$ & $3.16 \pm .72$ & 0.04 & 0.04 & 1.16 & 0.24 & $\begin{array}{c}-0.03 \text { to } \\
0.13\end{array}$ \\
\hline Manager job support & $3.53 \pm .79$ & $3.61 \pm .83$ & -0.07 & 0.05 & -1.45 & 0.15 & $\begin{array}{c}-0.18 \text { to } \\
0.02\end{array}$ \\
\hline Peer job support & $3.60 \pm .76$ & $3.68 \pm .74$ & -0.07 & 0.04 & -1.80 & 0.07 & $\begin{array}{c}-0.16 \text { to } \\
0.00\end{array}$ \\
\hline
\end{tabular}

$P \leq .05$ is considered significant. 
Table 5: Changes in pre and post-move objectively measured occupational sitting and physical activity and blood pressure $(n=50)$

\begin{tabular}{|c|c|c|c|c|c|}
\hline & \multicolumn{2}{|c|}{ Building Move } & \multirow[b]{3}{*}{$t$} & \multirow[b]{3}{*}{$P$} & \multirow[b]{3}{*}{$95 \% \mathrm{Cl}$} \\
\hline & Pre & Post & & & \\
\hline & $\mathrm{M} \pm \mathrm{SD}$ & $\mathrm{M} \pm \mathrm{SD}$ & & & \\
\hline $\begin{array}{l}\text { Sitting time (hours per } \\
\text { day) }\end{array}$ & $6.62 \pm 0.97$ & $6.31 \pm 0.90$ & 2.17 & 0.03 & $\begin{array}{c}0.02 \text { to } \\
0.58\end{array}$ \\
\hline $\begin{array}{l}\text { Standing time (hours } \\
\text { per day) }\end{array}$ & $1.34 \pm 0.48$ & $1.56 \pm 0.64$ & $\begin{array}{c}- \\
2.37\end{array}$ & 0.02 & $\begin{array}{c}-0.41 \text { to }- \\
0.03\end{array}$ \\
\hline $\begin{array}{l}\text { Stepping time } \\
\text { (minutes per day) }\end{array}$ & $0.70 \pm 0.25$ & $0.82 \pm 0.31$ & $\begin{array}{c}- \\
3.57\end{array}$ & 0.001 & $\begin{array}{c}-0.18 \text { to - } \\
0.05\end{array}$ \\
\hline $\begin{array}{l}\text { Systolic blood } \\
\text { pressure (mm Hg) }\end{array}$ & $127.14 \pm 13.27$ & $122.40 \pm 14.13$ & 3.85 & $<0.001$ & $\begin{array}{l}1.71 \text { to } \\
5.43\end{array}$ \\
\hline $\begin{array}{l}\text { Diastolic blood } \\
\text { pressure }(\mathrm{mm} \mathrm{Hg})\end{array}$ & $79.29 \pm 7.90$ & $75.71 \pm 8.56$ & 7.73 & 0.003 & $\begin{array}{l}1.71 \text { to } \\
7.73\end{array}$ \\
\hline
\end{tabular}

$P \leq .05$ is considered significant. 


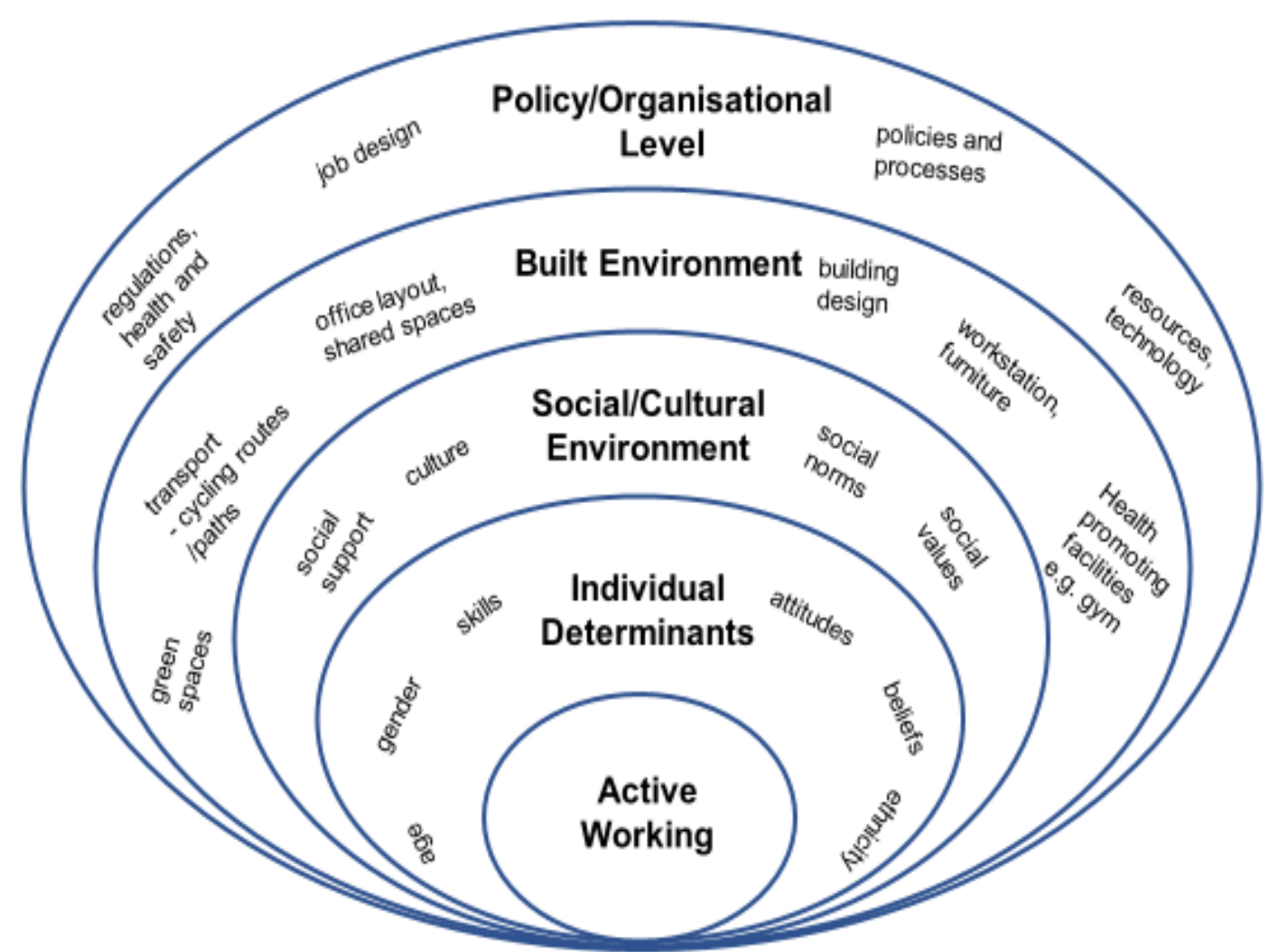

Figure 1. Ecological Model Adapted for workplace bullings with active design features (Sallis et al, 2012; Owen et al, 2011) 